AperTO - Archivio Istituzionale Open Access dell'Università di Torino

\title{
Naturally Occurring Asbestiform Minerals in Italian Western Alps and in Other Italian Sites
}

\section{This is the author's manuscript}

Original Citation:

Availability:

This version is available http://hdl.handle.net/2318/1715911

since 2020-02-26T18:14:05Z

Published version:

DOI:10.2113/EEG-2276

Terms of use:

Open Access

Anyone can freely access the full text of works made available as "Open Access". Works made available under a Creative Commons license can be used according to the terms and conditions of said license. Use of all other works requires consent of the right holder (author or publisher) if not exempted from copyright protection by the applicable law. 


\title{
Naturally Occurring Asbestiform Minerals in Italian Western Alps and in Other Italian Sites
}

\author{
BELLUSO Elena \\ Department of Earth Sciences, University of Torino, via Valperga Caluso n.35, 10125 Torino, Italy; \\ 00393358345402, elena.belluso@unito.it \\ Interdepartmental Centre “G. Scansetti”for Studies on Abestos and Other Toxic Particulates, \\ University of Torino, Italy \\ Institute of Geosciences and Earth Resources -IGG, National Research Council-CNR of Italy
}

\section{BARONNET Alain}

Centre Interdisciplinaire de Nanosciences de Marseille (CINaM), Université Aix-Marseille, France; Campus de Luminy, Case 913, 13288 Marseille Cedex 9, 00336629038 06, baronnet@cinam.univmrs.fr

\author{
CAPELLA Silvana \\ Department of Earth Sciences, University of Torino, via Valperga Caluso n.35, 10125 Torino, Italy; \\ 0039116705121, silvana.capella@unito.it \\ Interdepartmental Centre “G. Scansetti”for Studies on Abestos and Other Toxic Particulates, \\ University of Torino, Italy
}

\begin{abstract}
The natural occurrence of asbestos (NOA) in rocks and soil has been known for many years in several areas of the world, differently from the natural presence of asbestiform minerals. In Italy the mapping of NOA is mandatory according to the 2001 and 2003 regulations. The investigation, not yet concluded, has revealed that in Italy NOA are represented by chrysotile, tremolite asbestos with minor amount of actinolite asbestos and anthophyllite asbestos. A field survey carried out in Italian Western Alps (IWA), dealing with the naturally occurring of asbestiform minerals non-asbestos classified (NONA) and not regulated, started many years ago and is still ongoing. It revealed that the following kinds of asbestiform silicates are present (in decreasing order of frequency): asbestiform polygonal serpentine and asbestiform antigorite, asbestiform diopside, asbestiform carlosturanite, asbestiform
\end{abstract}


31 forsterite, asbestiform sepiolite, asbestiform balangeroite, and asbestiform talc. The asbestiform non-

32 silicates brugnatellite and brucite have been rarely detected. Outside the IWA, asbestiform zeolite

33 (erionite and offretite), asbestiform sodium amphibole (fluoro-edenite), and few other asbestiform

34 silicates have been also detected. For some asbestiform minerals, the identification is problematic and needs the use of transmission electron microscope (TEM) combining either the imaging at high magnification as the electron diffraction and the chemical data. This investigation is particularly important to distinguish four kinds of asbestiform minerals (antigorite, polygonal serpentine, carlosturanite, and balangeroite) from chrysotile since only the last one is regulated. The issue is much more complicated by the intergrowth of different fibrous species on the scale of sub micrometre.

Keywords: NOA; naturally occurring non-asbestos classified asbestiform minerals (NONA); TEM-

EDS identifications; fibre intergrowth

\section{Introduction}

In recent years and in several countries the health investigations dealing with asbestos moved

from the occupational to environmental exposure (e.g., Baumann et al., 2015; Abakay et al., 2016;

47 Noonan, 2017). According some authors in fact the exposure to low but continuous exposure, as in the case of inhabitants of houses next to the asbestos bearing rock outcrops (i.e. naturally occurring asbestos: NOA), could cause health problems (e.g., Luce et al., 2000; Bernardini et al., 2003). The same problem could concern the exposure to naturally occurring non-asbestos classified asbestiform minerals (NONA). For some of them, the carcinogenicity to high dose exposure is known as in the case of asbestiform fluoeredenite, asbestiform erionite, asbestiform winchite, and asbestiform richterite

\section{3 (e.g., Burragato et al., 2005, IARC, 2012). In addition to these last minerals, many others having an}


striking current example is represented by asbestiform antigorite. For many years this antigorite asbestiform variety has not been recognized as having a full identity and little information has appeared in few publications (e.g., Keeling et al., 2006).

But, exactly as it happens for the NOA, also the NONA can be dispersed in air both for natural causes (weathering, natural atmospheric agents, landslide) and for anthropogenic causes (e.g. excavation works).

If these asbestiform minerals are noxious following continuous low dose and/or sporadic high doses, it will be known only in many years, as it has happened for example for asbestos given the long latency time of related asbestos pathologies. For the instance, it would be a good practice to map the presence of these minerals in every country.

As it concerns Italy, the mapping of NOA is mandatory according to the March 23, $2001 \mathrm{Law}, \mathrm{n}$. 93 and to the related March 18, 2003, Environment Ministry Decree, n. 101. The mapping of NOA must be carried out by each single Region through its own Environmental Protection Agency, using literature data, geological maps, historical information on research permits and mining concessions, reports and environmental monitoring carried out as part of environmental and strategic impact assessment procedures for the construction of infrastructural works, analytical certificates, mining activities of lithotypes suspected for the presence of asbestos, surveys for the Geological Cartography project at 1: 50,000 scale, specific investigations and surveys, possible inspections and sometimes collection of samples and laboratory analyses. Each year the individual EPA send any possible additional data to the Ministry of Health that integrates it to the aim of the evaluation of the necessary remediation works.

Currently, the map of the Italian NOA is published from the Ministry of the Environment and Protection of the Territory and the Sea; it is updated to the year 2018 and reports NOA sites only from three regions (Asbestos Mapping, 2018) but to the current state of scientific knowledge, NOA are 
79 80 in Italy.

81

82

83

84

85

86

87

88

89

90

91

92

93

94

95

96

97

98

99

100

101

(81 below.

present in at least 7 other regions. This paper presents the different NOA and NONA until now detected

\section{Detected NOA and NONA}

Firstly, owing to the different used definitions, it needs to define the meaning of the used words.

According to the dimensional definition of the World Health Organization (WHO, 1997), many

regulatory agencies and the literature (e.g. Belluso et al., 2017), in this note we use the definition listed

Fiber: inorganic particle with length $\geq 5 \mu \mathrm{m}$, width $\leq 3 \mu \mathrm{m}$, length/width (aspect ratio) $\geq 3: 1$, parallel sides when seen in two dimensions, perpendicularly to fiber axis.

Fibril: a single mineral fiber which cannot be further separated longitudinally into smaller components (without losing the fibrous properties or appearances).

Asbestiform: adjective for fibers non asbestos classified having the "fiber" dimensions and at least one of the asbestos properties as flexibility, splitting etc.

Fiber bundle: parallel aggregate of mineral fibers.

In the scientific literature many researches touch the NOA topic. Some of them have been carried out specifically for mineralogical interests, others concern petrological, structural engineering or geology studies; sometimes the scientific investigations arise from minerals collectors. In any case, their identification is carried out by using different techniques, in some cases by using two or more than two in a complementary way. The most diffused identification techniques are X-ray powder diffractometry (XRPD), infrared spectroscopy (with Fourier transform), optical (OM) and electron microscopy (EM), usually scanning (SEM) and uncommonly transmission (TEM), coupled with energy dispersive spectrometry (EDS). 

chrysotile and tremolite asbestos (both very diffused), the less diffused actinolite asbestos and finally anthophyllite asbestos that is the much less diffused than others (e.g., Cavallo and Rimoldi, 2013;

Gaggero et al., 2013; Vignaroli et al., 2013; Gaggero et al., 2017). The Figure 1 shows the 10 Regions where NOA are present in rocks, at the current state of knowledge. Crocidolite and amosite do not constitute NOA in Italy. carried out during both the asbestos investigation and specific mineralogical researches, show that NONA are present in many Italian areas (8 Italian Regions) and abundant in some places. Except Piedmont and Aosta Valley Regions which we will discuss later, the NONA identified in Italy are the following (in alphabetic order): asbestiform antigorite, asbestiform Ca-erionite (with Ca-levyne), asbestiform F-edenite, asbestiform gedrite, asbestiform $\mathrm{Mg}$-horneblende, asbestiform offretite, asbestiform polygonal serpentine, asbestiform sepiolite (e.g., Cattaneo et al., 2011; Bloise et al., 2014;.Bloise et al., 2016; Bloise et al., 2017; Giordani et al., 2017; Lucci et al., 2018; Mattioli et al., 2018) The Italian Regions where these asbestiform minerals have been detected are shown in Figure 2. Regarding the Italian Western Alps (IWA) Regions, i.e. Piedmont and Aosta Valley, a field survey dealing with NOA is carried out since 1980 and it is still ongoing (Baronnet and Belluso, 2002; Belluso et al., 2015; Leone, 2018; Paccagnella, 2018). More than 300 samples have been collected and analyzed by using XRPD coupled with SEM-EDS and/or TEM-EDS. As NOA, chrysotile, asbestos tremolite, and, in lesser amount, asbestos actinolite have been detected. kinds of asbestiform silicates (sometimes in very high amount) of NONA, not regulated in Italy. Ten are the identified NONA and eight of these are magnesium-containing silicates (Table 1). The complete list is shown below, in decreasing order of frequency: asbestiform polygonal serpentine and 
asbestiform antigorite (with very high frequency); asbestiform diopside, asbestiform carlosturanite,

127 asbestiform forsterite, asbestiform sepiolite, asbestiform balangeroite, and asbestiform talc. Rare are asbestiform brugnatellite and asbestiform brucite, the only two non-silicates asbestiform minerals.

As far as quantities are concerned, asbestiform carlosturanite and asbestiform balangeroite are very abundant. As regards the quantities of asbestiform antigorite and asbestiform polygonal serpentine, is not possible to define the amount because these two minerals are always intergrown with others fibrous minerals, asbestos and non asbestos classified.

For some asbestiform minerals, the certain identification is not so easy because they show similar (at times even equal) characteristics on a macroscopic scale. As it concerns NOA and NONA in IWA Regions, on the macroscopic scale in most cases it is not possible distinguish among chrysotile, asbestiform antigorite, asbestiform polygonal serpentine, asbestiform carlosturanite, and asbestiform balangeroite. Figure 3 shows an example of this similarity on the eye scale, both in outcropping rocks and after picking fibers from the rock, between asbestiform antigorite (Figs. 3a and 3b) and chrysotile (Fig. 3c). The bundles of fibres are flexible and their characteristics are very similar to each other. Also the colour is similar because chrysotile containing a little amount of iron has not white colour but cream to light brown.

Often it needs the use of the transmission electron microscope (TEM) combining either the imaging at high magnification as the selected area electron diffraction (SAED) and the chemical data 144 (EDS).

This investigation is particularly important to distinguish four kinds of NONA and specifically asbestiform antigorite (Fig. 4), asbestiform polygonal serpentine (Fig. 4), asbestiform carlosturanite, and asbestiform balangeroite, from chrysotile (Fig. 4) since only the last one is regulated, being asbestos classified. The issue is very complicated because usually, on the scale of little thousands or 
149 even hundreds micrometers, the fibers of two to four mineral species are intergrown (owing to solid 150 state transformations) as it can see in Fig. 4.

151 Based on the detailed investigation by TEM-EDS, practically each bundle of fibers turns out to be 152 made up of at least 2 fibrous mineral species, except in the case of asbestiform sepiolite, which on the 153 other hand appears to have only intergrown with an organic phase (aliphatic hydrocarbons: Giustetto et 154 al., 2014). sampling, the importance of the use of the technique suitable to identify the content of these composite materials (i.e. the bundle of fibers), the need of the extended surveys for extensive investigations where 171 there are rocks that may contain mineral fibers. 
173 like those from Italian Western Alps rocks.

174 


\section{References}

176 Abakay, A.; Tanrikulu, A. C. ; Ayhan, M. ; Imamoglu, M. S. ; Taylan, M. ; Kaplan, M. A.; and

177 Abakay, O., 2016, High-risk mesothelioma relation to meteorological and geological condition and 178 distance from naturally occurring asbestos: Environmental Health Preventive Medicine, Vol. 21, pp. $179 \quad 82-90$.

180 Baronnet, A.; and Belluso, E., 2002, Microstructures of the silicates: key information about mineral 181 reactions and a link with the Earth and materials sciences: Mineralogical Magazine, Vol. 66, pp. 709182735.

Baumann, F.; Buck, B.J.; Metcalf, R.V.; McLaurin, B.T.; Merkler, D.J.; and Carbone, M., 2015, The presence of asbestos in the natural environment is likely related to mesothelioma in young individuals and women from Southern Nevada: Journal Thoracic Oncology, Vol. 10, pp. 731-737.

Belluso, E.; Cavallo, A.; and Halterman, D., 2017, Crystal habit of mineral fibres: European

Mineralogical Union Notes in Mineralogy, Vol. 18, pp. 65-109.

Belluso, E.; Compagnoni, R.; and Ferraris, G., 1995, Occurrence of asbestiform minerals in the serpentinites of the Piemonte Zone, Western Alps. In Politecnico di Torino (Editor), Giornata di Studio in ricordo del Prof. Stefano Zucchetti, Torino, pp. 57-64.

Bernardini, P.; Schettino, B.; Sperduto, B.; Giannandrea, F.; Burragato, F.; and Castellino, N., 2003, 192 Three cases of pleural mesothelioma and environmental pollution with tremolite outcrops in Lucania:

Giornale Italiano Medicina Lavoro Ergonomia, Vol. 25, pp. 408-411.

Bloise, A.; Catalano, M.; Critelli, T.; Apollaro, C.; and Miriello, D., 2017, Naturally occurring asbestos: potential for human exposure, San Severino Lucano (Basilicata, Southern Italy):

197 Bloise, A.; Critelli, T.; Catalano, M.; Apollaro, C.; Miriello, D.; Croce, A.; Barrese, E.; Liberi, F.; 198 Piluso, E.; Rinaudo, C.; and Belluso, E., 2014, Asbestos and other fibrous minerals contained in the 
200 Sciences, Vol. 71, pp. 3773-3786.

201 Bloise, A.; Punturo, R.; Catalano, M.; Miriello, D.; and Cirrincione, R., 2016, Naturally occurring 202 asbestos (NOA) in rock and soil and relation with human activities: the monitoring example: Italian 203 Journal Geosciences, Vol. 135, pp. 268-279.

204 Burragato, F.; Comba, P.; Baiocchi, V.; Palladino, D.M.; Simei, S.; Gianfagna, A.; Paoletti, L.; and 205 Pasero, R., 2005, Geo-volcanological, mineralogical and environmental aspects of quarry materials 206 related to pleural neoplasm in the area of Biancavilla, Mount Etna (Eastern Sicily, Italy):

207 Environmental Geology, Vol. 47, pp. 855-868.

208 Cattaneo, A.; Rossotti, A.; Pasquaré, G.; Somigliana, A.; and Cavallo, D. M., 2011, Analysis of fibrous 209 zeolites in the volcanic deposits of the Viterbo Province, Italy: Environmental Earth Sciences, Vol. 63, 210 pp. 861-871.

211 Cavallo, A.; and Rimoldi, B., 2013, Chrysotile asbestos in serpentinite quarries: A case study in 212 valmalenco, central alps, northern Italy: Environmental Sciences: Processes Impacts, Vol. 15, pp. 213 1341-1350.

214 Gaggero, L.; Crispini, L.; Isola, E.; and Marescotti, P., 2013, Asbestos in natural and anthropic 215 ophiolitic environments: a case study of geohazards related to the Northern Apennine ophiolites 216 (Eastern Liguria, Italy): Ofioliti, Vol. 38, pp. 29-40.

217 Gaggero, L.; Sanguineti, E.; Gonzalez, A. Y.; Militello, G. M.; Scuderi, A.; and Parisi G., 2017, 218 Airborne asbestos fibres monitoring in tunnel excavation: Journal of Environmental Management, Vol. 219196, pp. 583-593.

220 Giordani, M.; Mattioli, M.; Ballirano, P.; Pacella, A.; Cenni, M.; Boscardin, M.; and Valentini, L., 221 2017, Geological occurrence, mineralogical characterization, and risk assessment of potentially 
222 carcinogenic erionite in Italy: Journal Toxicology Environmental Health, Part B, Critical Reviews, 223 Vol. 20, pp. 81-103.

224 Giustetto, R.; Seenivasan, K.; and Belluso, E., 2014, Asbestiform sepiolite coated by aliphatic 225 hydrocarbons from Perletoa, Aosta Valley Region (Western Alps, Italy): characterization, genesis and 226 possible hazards: Mineralogical Magazine, Vol. 78, pp. 919-940.

227 International Agency for Research on Cancer, Monographs, IARC, 2012, Asbestos (chrysotile, amosite, 228 crocidolite, tremolite, actinolite, and anthophyllite). In Evaluation of Carcinogenic Risks to Humans. A 229 Review of Human Carcinogens. International Agency for Research on Cancer, Monographs, Vol. 100, 230 Part C: Arsenic, Metals, Fibres, and Dusts, Lyon, France, pp. 219-309.

231 Keeling, J.L.; Raven, M.D.; and McClure, S.G., 2006, Identification of fibrous mineral from Rowland 232 Flat area, Barossa Valley, South Australia, Primary Industries and Resources South Australia, 233 Adelaide, Report Book 2006/00002, 23 p.

234 Leone, C., 2018, Mineralogical and petrographic characterization of fibrous minerals and of their 235 hosting rocks exposed in the north-western Voltri Group and Sestri-Voltaggio Zone, Alessandria 236 province: Unpublished post graduate thesis, Department of Earth Sciences, University of Torino, Italy, $237180 \mathrm{p}$.

238 Lucci, F.; Della Ventura, G.; Conte, A.; Nazzari, M.; and Scarlato, P., 2018, Naturally Occurring 239 Asbestos (NOA) in Granitoid Rocks, A Case Study from Sardinia (Italy): Minerals, Vol. 8, pp. 442240464.

241 Luce, D.; Bugel, I.; Goldberg, P., Goldberg, M.; Salomon, C.; Billon-Galland, M.A.; Nicolau, J.;

242 Quénel, P.; Fevotte, J.; and Brochard P., 2000, Environmental exposure to tremolite and respiratory 243 cancer in New Caledonia: a case-control study: American Journal Epidemiology, Vol. 151, pp. 259244265. 
245 Mattioli, M.; Giordani, M.; Arcangeli, P.; Valentini, L.; Boscardin, M.; Pacella, A.; and Ballirano, P., 246 2018, Prismatic to Asbestiform Offretite from Northern Italy: Occurrence, Morphology and Crystal-

247 Chemistry of a New Potentially Hazardous Zeolite: Minerals, Vol. 8, pp. 69-84.

248 Meeker, G.P.; Bern, A.M.; Brownfield, I.K.; Lowers, H.A.; Sutley, S.J.; Hoefen, T.M.; and Vance, J.S., 249 2003, The Composition and Morphology of Amphiboles from the Rainy Creek Complex, Near Libby, 250 Montana: American Mineralogist, Vol. 88, pp. 1955-1969.

251 Ministry of the Environment and Protection of the Territory and the Sea, 2018, Asbestos mapping:

252 https://www.minambiente.it/sites/default/files/bonifiche/Mappatura_amianto/mappatura_amianto_2018

$253 . . \mathrm{pdf}$

254 Noonan, C. W., 2017, Environmental asbestos exposure and risk of mesothelioma: Annals

255 Translational Medicine, Vol. 5, pp. 234-244.

256 Paccagnella, G., 2018, Mineralogical and petrographical characterization of asbestiform phases and of

257 their host rocks from the north-western Voltri Massif: Unpublished post graduate thesis, Department of 258 Earth Sciences, University of Torino, Italy, $182 \mathrm{p}$.

259 Vignaroli, G.; Ballirano, P.; Belardi, G.; and Rossetti, F., 2013, Asbestos fibre identification vs. 260 evaluation of asbestos hazard in ophiolitic rock mélanges, a case study from the Ligurian Alps (Italy):

261 Environmental Earth Sciences, Vol. 72, pp. 3679-3698.

262 World Health Organization, WHO, 1997, Determination of airborne fibre number concentrations; a 263 recommended method, by phase contrast optical microscopy (membrane filter method): World Health 264 Organization, Geneva, Switzerland, 53 p. 
TABLE CAPTIONS

266 Table 1. List of NONA in decreasing order of finding frequency, detected in Piedmont and Aosta

267 Valley Regions, North-Western Alps, Italy and the ideal chemical- formula.

268 Table 2. Parallel intergrowths of asbestos and asbestiform minerals after investigations by TEM-EDS.

269 The most abundant asbestiform minerals (main) and the intergrown minerals (subordinate) in the same

270 bundle are listed in the left and in the right column, respectively. (asbestos are indicated in italic-

271 Italian legislation 277/91).

\section{FIGURE CAPTIONS}

274 Figure 1. Italian regions and mineral species of naturally occurring asbestos (NOA) in rocks:

275 chrysotile, tremolite asbestos, less diffused actinolite asbestos, and rare anthophyllite asbestos.

276 Figure 2. Italian regions and mineral species of naturally occurring non-asbestos classified asbestiform

277 minerals (NONA) in rocks: asbestiform antigorite, asbestiform Ca-erionite with Ca-levyne, asbestiform

278 F-edenite, asbestiform gedrite, asbestiform Mg-horneblende, asbestiform offretite, asbestiform

279 polygonal serpentine, asbestiform sepiolite. For Aosta Valley and Piedmont Regione, details are in the text.Figure 3. Macroscopic similarity of mineral fibre bundle. A) Vein filled of asbestiform antigorite. B) Fibrous bundles of asbestiform antigorite. C) Fibrous bundles of chrysotile.

282 Figure 4. TEM image of cross-section of an asbestiform composite made of axially-textured 283 intergrown fibrils of asbestiform antigorite (atg) with minor asbestiform polygonal serpentine (PS) and 284 chrysotile (chrys). 


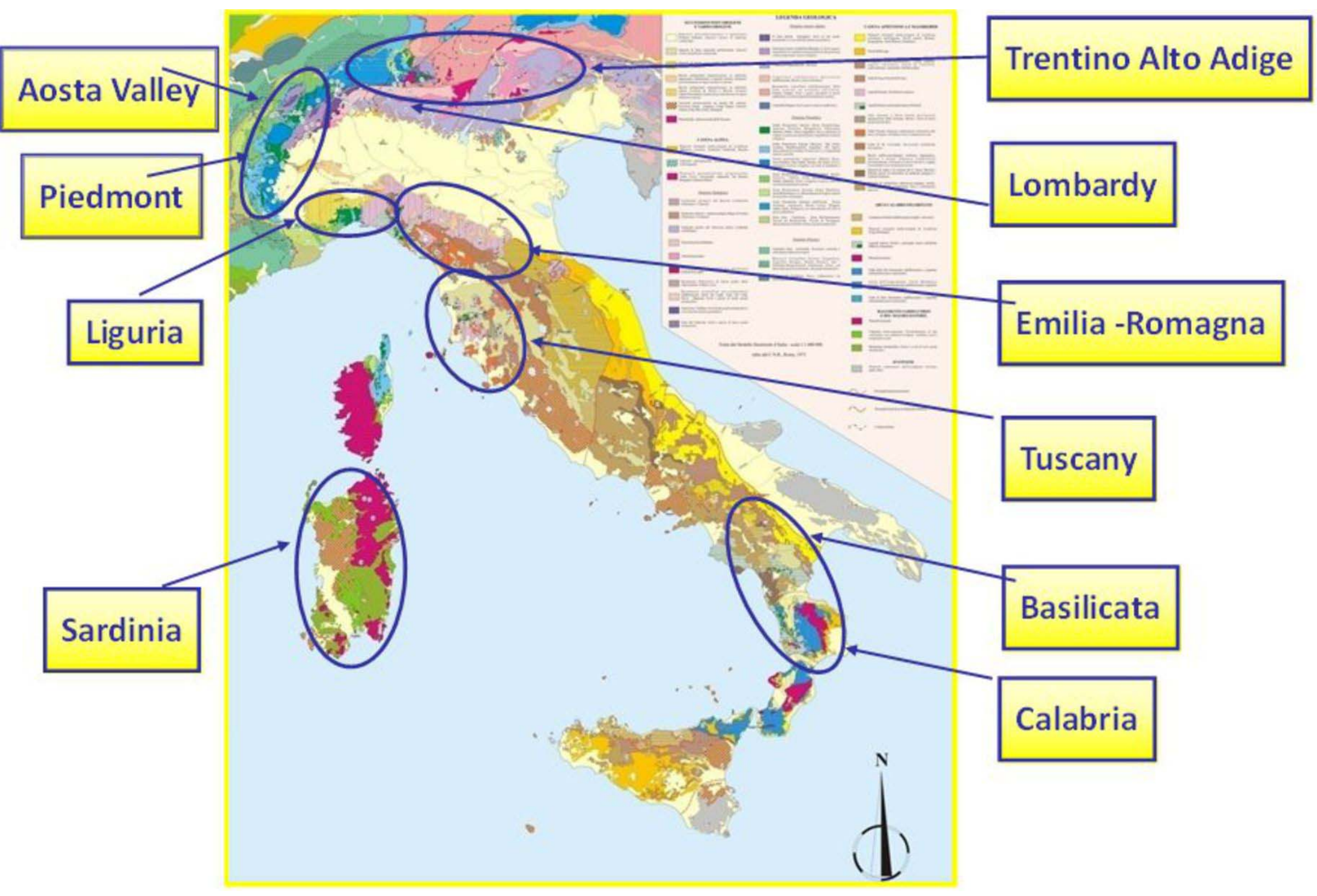




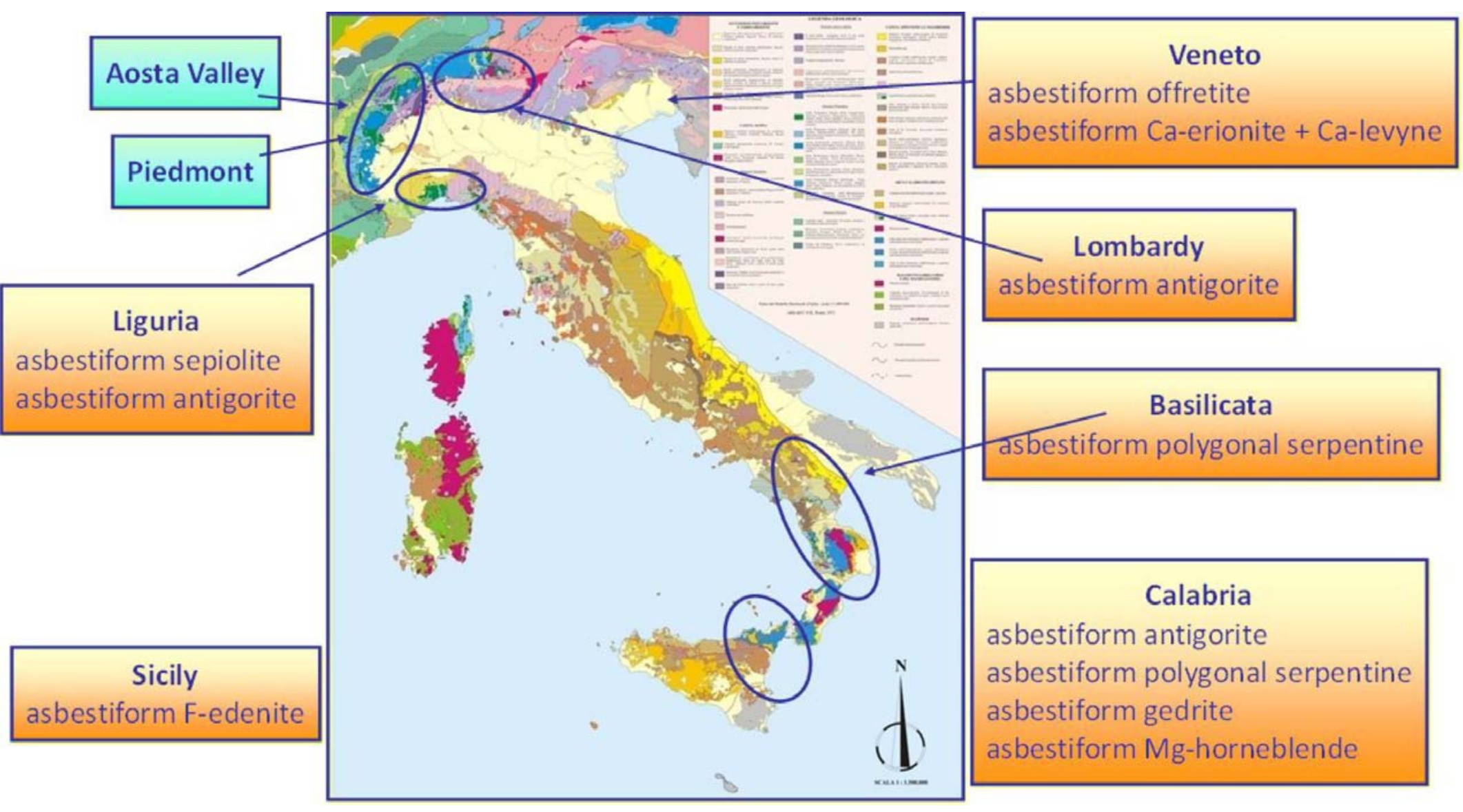



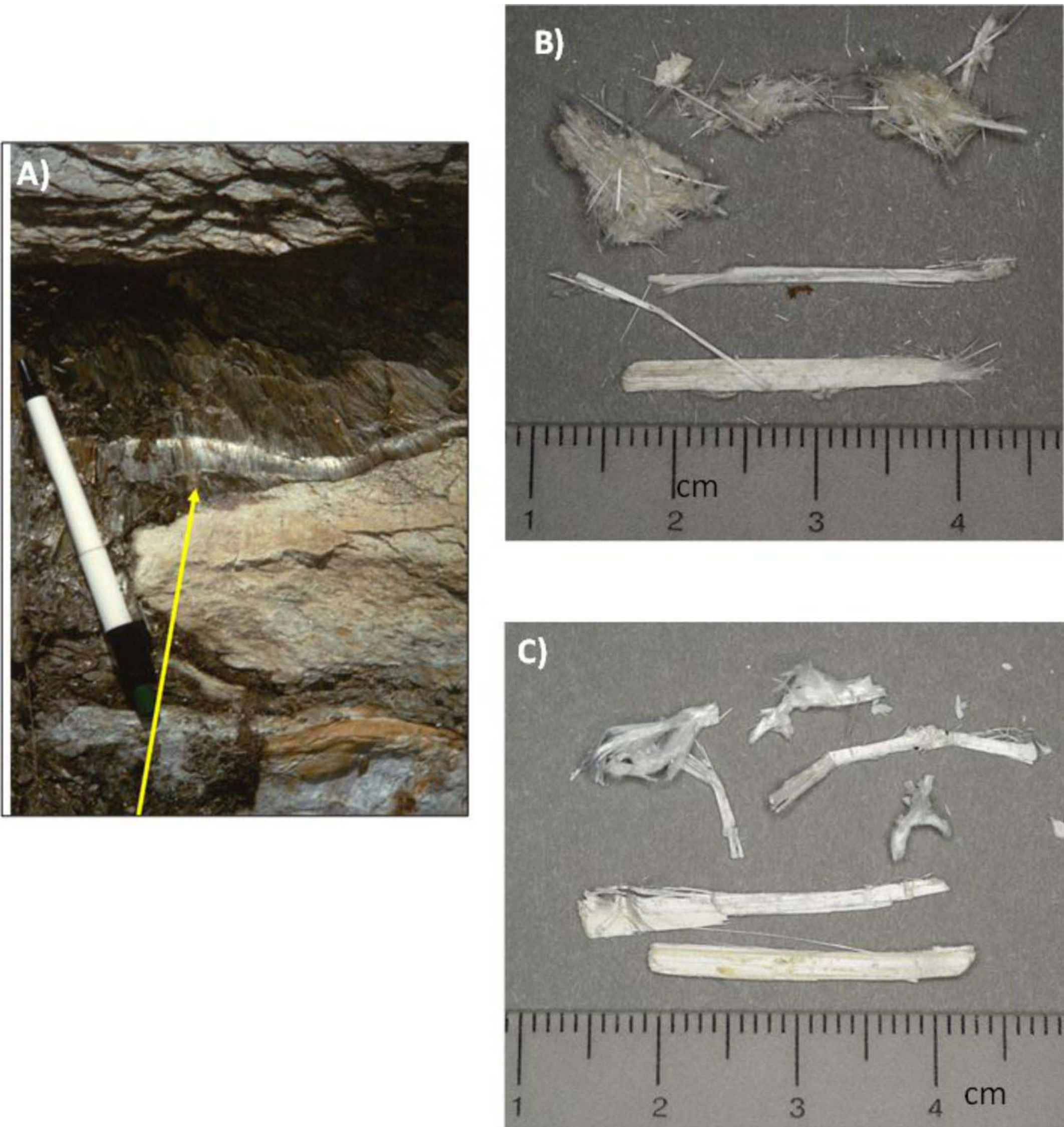


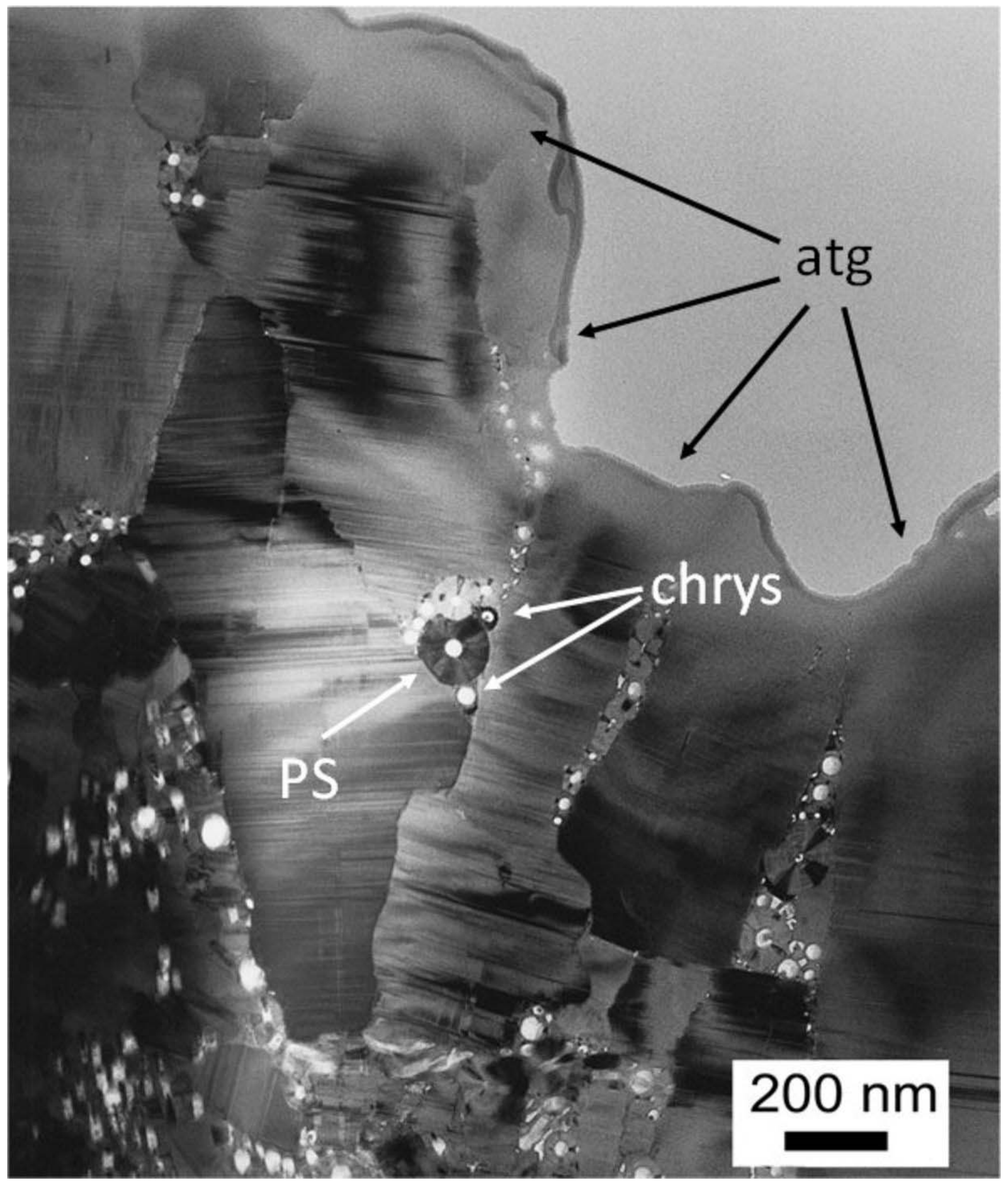




\begin{tabular}{|c|c|}
\hline NONA & Ideal chemical formula \\
\hline asbestiform polygonal serpentine, asbestiform antigorite & $\mathrm{Mg}_{3} \mathrm{Si}_{2} \mathrm{O}_{5}(\mathrm{OH})_{4}$ \\
\hline asbestiform diopside & $\mathrm{CaMgS}_{\mathrm{i}_{2}} \mathrm{O}_{6}$ \\
\hline asbestiform carlosturanite & $(\mathrm{Mg}, \mathrm{Fe}, \mathrm{Ti})_{21}\left[\mathrm{Si}_{12} \mathrm{O}_{28}(\mathrm{OH})_{4}\right](\mathrm{OH})_{30} \cdot \mathrm{H}_{2} \mathrm{O}$ \\
\hline asbestiform forsterite & $\mathrm{Mg}_{2} \mathrm{SiO}_{4}$ \\
\hline asbestiform balangeroite & $(\mathrm{Mg}, \mathrm{Fe}, \mathrm{Mn})_{21} \mathrm{O}_{3}(\mathrm{OH})_{20}\left(\mathrm{Si}_{4} \mathrm{O}_{12}\right)_{2}$ \\
\hline asbestiform sepiolite & $\mathrm{Mg}_{4} \mathrm{Si}_{6} \mathrm{O}_{15}(\mathrm{OH})_{2} \cdot 4 \mathrm{H}_{2} \mathrm{O}$ \\
\hline asbestiform talc & $\mathrm{Mg}_{3} \mathrm{Si}_{4} \mathrm{O}_{10}(\mathrm{OH})_{2}$ \\
\hline asbestiform brugnatellite & $\mathrm{Mg}_{6} \mathrm{Fe}\left(\mathrm{CO}_{3}\right)(\mathrm{OH})_{13} \cdot 4 \mathrm{H}_{2} \mathrm{O}$ \\
\hline asbestiform brucite & $\mathrm{Mg}(\mathrm{OH})_{2}$ \\
\hline
\end{tabular}

Table 1. List of NONA in decreasing order of finding frequency, detected in Piedmont and Aosta Valley Regions, North-Western Alps, Italy and the ideal chemical-formula. 


\begin{tabular}{|l|l|}
\hline \multicolumn{1}{|c|}{ MAIN MINERAL } & \multicolumn{1}{c|}{ SUBORDINATE MINERALS } \\
\hline $\begin{array}{l}\text { chrysotile + asbestiform } \\
\text { polygonal serpentine }\end{array}$ & $\begin{array}{l}\text { asbestiform antigorite, asbestiform diopside, asbestiform carlosturanite, } \\
\text { asbestiform forsterite, asbestiform balangeroite }\end{array}$ \\
\hline $\begin{array}{l}\text { asbestiform antigorite } \\
\text { asbestos tremolite } \\
\text { (asbestos actinolite) }\end{array}$ & $\begin{array}{l}\text { chrysotile + asbestiform polygonal serpentine, asbestos tremolite, } \\
\text { asbestiform talc }\end{array}$ \\
\hline asbestiform diopside & $\begin{array}{l}\text { chrysotile + asbestiform polygonal serpentine, asbestiform antigorite, } \\
\text { asbestiform carlosturanite, asbestiform balangeroite, asbestiform } \\
\text { brugnatellite }\end{array}$ \\
\hline asbestiform carlosturanite & $\begin{array}{l}\text { chrysotile + asbestiform polygonal serpentine, asbestiform diopside, } \\
\text { asbestiform antigorite, asbestiform forsterite, asbestiform brucite }\end{array}$ \\
\hline asbestiform forsterite & chrysotile + asbestiform polygonal serpentine, asbestiform carlosturanite \\
\hline asbestiform balangeroite & chrysotile + asbestiform polygonal serpentine, asbestiform diopside \\
\hline asbestiform brugnatellite & asbestiform diopside \\
\hline asbestiform brucite & asbestiform diopside \\
\hline asbestiform sepiolite & “organic matter" \\
\hline
\end{tabular}

Table 2. Parallel intergrowths of asbestos and asbestiform minerals after investigations by TEMEDS. The most abundant asbestiform minerals (main) and the intergrown minerals (subordinate) in the same bundle are listed in the left and in the right column, respectively. (asbestos are indicated in italic- Italian legislation 277/91). 